\title{
ASSITANCE OF FEMALE MIGRANT WORKERS (Case Study of the Migrant Workers Care Village Program (Desbumi) in Darek Village, Southwest Praya District, Central Lombok Regency)
}

\author{
Rohimi
}

Universitas Islam Negeri Sunan Kalijaga Yogyakarta, Dinobastian11@gmail.com

\author{
(1) (1) \\ C) 2020 by the authors. Submitted for possible open access publication under the terms and conditions \\ of the Creative Commons Attribution-ShareAlike 4.0 International License (CC-BY-SA) \\ license (https://creativecommons.org/licenses/by-sa/4.0/) \\ (4. DOI :bttp://dx.doi.org/10.30983/ bumanisme.v5i2

\begin{tabular}{l|l|l} 
Submission: January 14, 2021 & Revised: December 16, 2021 & Published: December 31, 2021
\end{tabular}

\begin{abstract}
In this study, researchers examined the role of the Village Care for Migrant Workers (Desbumi) program in mentoring female migrant workers in Darek. Village, Praya Barat Daya District, Central Lombok Regency. This research is field research with data collection steps, namely interviews, documentation and observation. Therefore, this research aims o find out female migrant worker assistance patterns through the Desbumi program in Darek Village, Praya Barat Daya District, Central Lombok. Regency. The results and discussion in this study are that the Desbumi program has three roles. First. Information center provides information to migrant workers about safe and legal migration (safety migrations). Second is the mobility data center, which assists prospective migrant workers in arranging migration filings at the village office. Third, the center for case advocacy, namely the role in providing protection and assistance to migrant workers who experience problems abroad. Meanwhile, the pattern of assisting female migrant workers in the Desbumi program approach is namely. First, pre-work mentoring, namely conducting socialization to the community by bringing migration flyers that have been given by Migrant Care and from the BNP2TKI office in Central Lombok Regency. It then provides an opportunity for people to ask questions about safe migration. Second, after work assistance, the Desbumi program can carry out consolidation and integration with Migrant Care, PPK and BNP2TKI if they encounter problems with migrant workers abroad. Furthermore, they confirm through social media with the Desbumi program in Darek. Village, Praya Barat Daya District, Central Lombok. Regency. Third, post-work mentoring, where former migrant workers are empowered in the village with various empowerment approaches. These approaches included making crackers, chips, sewing training and soft skills activities supported by the village government, Migrant Care, the Mataram City Panca Karsa Association (PPK), and BNP2TKI Central Lombok Regency
\end{abstract}

Keywords: Assistance, Female Migrant Workers, Desbumi Program

\begin{abstract}
Abstrak
Dalam penelitian ini, peneliti mengkaji peran dari program Desa Peduli Buruh Migran (Desbumi) dalam pendampingan buruh migrant perempuan di Desa Darek Kecamatan Praya Barat Daya Kabupaten Lombok Tengah. Penelitian ini merupakan penelitian lapangan dengan langkah pengumpulan data yakni wawancara, dokumentasi dan observasi. Oleh karenaitu, tujuan dalam penelitian ini yakni untuk mengetahui bagaimana pola pendampingan buruh migrant perempuan melalui program Desbumi di Desa Darek Kecamatan Praya Barat Daya Kabupaten Lombok Tengah. Hasil dan pembahasan dalam penelitian ini yakni, bahwasannya program Desbumi memiliki tiga peran seperti. Pertama. Pusat Informasi yakni untuk memberikan informasi pada buruh migrant tentang bermigrasi yang aman yang legal. Kedua, pusat data mobilitas yakni untuk membantu calon buruh migrant mengurus pemberkasan migrasi di kantor desa. Ketiga, pusat advokasi kasus yakni peran dalam memberikan perlindungan dan pendampingan pada buruh migran yang mengalami
\end{abstract}




\begin{abstract}
permasalahan di luar negeri. Sedangkan pola pendampingan buruh migrant perempuan dalam pendekatan program Desbumi yakni. Pertama, pendampingan sebelum bekerja yakni melakukan sosialisasi ke masyarakat dengan membawa pamphlet migrasi yang sudah diberikan oleh pihak Migrant Care serta dari kantor BNP2TKI Kabupaten Lombok Tengah. Kemudian memberikan kesempatan bagi masyarakat untuk bertanya tentang migrasi yang aman. Kedua, pendampingan setelah bekerja yakni program Desbumi dapat melakukan dengan konsolidasi dan integrasi dengan Migran Care, PPK dan BNP2TKI jika menerima problematika buruh migran di luar negeri, dan melakukan konfirmasi melalui media social dengan adanya program Desbumi di Desa Darek Kecamatan Praya Barat Daya Kabupaten Lombok Tengah. Ketiga, pendampingan purna bekerja yakni mantan buruh migrant diperdayakan di desa dengan berbagai pendekatan pemberdayaan yakni pembuatan kerupuk, keripik, pelatihan menjahit dan kegiatan soft skill yang di dukung oleh pemerintah desa, pihak Migran Care, pihak Perkumpulan Panca Karsa (PPK) Kota Mataram, dan BNP2TKI Kabupaten Lombok Tengah.
\end{abstract}

Kata kunci: Pendampingan, Buruh Migran Perempuan, Program Desbumi

\section{Introduction}

The phenomenon of migrant workers is still a study that is in great demand until now. Migrant workers are the terminology of people who work beyond their own national borders. Therefore, becoming a migrant worker is also the basis of the society to upgrade the quality of their economy. It means that by becoming a migrant worker so that people can achieve prosperity and escape from adversity or poverty. ${ }^{1}$

Because it is undeniable if the condition of the people who are still shackled by poverty and see the reality of the employment entity in their own country is still difficult to obtain. In Indonesia, the magnitude of the poverty rate is a benchmark for people to migrate and become migrant workers abroad. In addition, the factors that cause people to migrate are not only from weak opportunities from employment, but

${ }^{1}$ Dian Permata Sari, "Analisis Peran Tenaga Kerja Wanita Di Luar Negeri Dalam Meningkatkan Pendapatan Keluarga Menurut Perspektif Ekonomi Islam," Skripsi: Universitas Raden Intan Lampung, 2017, 18-20. because of the low wages they get, so they make discretion to work abroad. ${ }^{2}$

High wages are their goal of traveling abroad to work. ${ }^{3}$ However, as we know from several analyses and theories about migrant workers, not all reap the rewards. Sometimes, they even return home with conditions that do not bring prosperity to themselves and their families. According to zuhdan (2008), that the phenomenon of migrant workers also often experiences various kinds of problems and problems in their place of work, such as experiencing acts of discrimination, work accidents and even many migrant workers from Indonesia who die in the destination country where they work. ${ }^{4}$

Becoming a migrant worker is a community option. Because if one does not work, they will not be able to support their family. Work is so important to achieve

${ }^{2}$ Ana Sabhana Azmy, Negara Dan Burub Migran Perempuan (Jakarta: Obor Indonesia, 2012), 3-5.

3Bubun Ni'matur Rohmah, "Tingkat Kesejahtraan Ekonomi Keluarga Buruh Migran," Jurnal Penelitian Ilmiah Intaj Vol 1, No 1 (2017): 171.

${ }^{4}$ Muhammad Zuhdan, "Perjuangan Gerakan Buruh Tidak Sekedar Upah Melacak Perkembangan Isu Gerakan Buruh Di Indonesia Pasca Reformasi," Jurnal Ilmu Sosial Dan Ilmu Politik Vol 17, No 3 Maret (2014): 273-274. 
material. According to Khaldun (2008), work is a way to get food because Allah has created human nature to work in order to be able to meet basic needs such as food if you want to survive and carry on life. ${ }^{5}$ Suseno (2005) also argues that work is a right and it is very urgent in human life to fulfill their needs. Therefore, by working, humans can earn a living and can use themselves for the work they do. ${ }^{6}$

On the other hand, those who become migrant workers are driven by the intention to fulfill their daily needs. In addition, the existence of migrant workers is also a strategy to improve the economy internally and reduce poverty levels in a country. Primarily, the community aims to work abroad to improve their welfare and escape from poverty. ${ }^{7}$ Therefore, poverty becomes a thing that haunts his life, where poverty can also occur from several factors such as laziness not wanting to work, afraid of not wanting to try, afraid of losing, weak in knowledge, with the existence of working abroad as proof in order to get out of the country poverty condition. ${ }^{8}$

A prosperous life is an achievement and everyone wants to be prosperous and well off. According to Aristotle, quoted by Mahfud (2009), Sufficient as an expectation that humans desire and as a form of potential realization of the will and actions taken to achieve this sufficiency. ${ }^{9}$ So that the

${ }^{5}$ Ibnu Khaldun, Muqoddimah (Jakarta: Pustaka Firdaus, 2008), 73.

${ }^{6}$ Franz Magnis Suseno, Pemikiran Karl Marx Dari Sosialisme Utopis Ke Perselisihan Revisionisme (Jakarta: Pt Gramedia Pustaka Utama, 2005), 96-97.

${ }^{7}$ Novie Kurniawati, "Prilaku Berpacaran Pada Remaja Usia Madya: Studi Kasus Di Daerah Di Kabupaten Merangin Provinsi Jambi" (Skripsi Universitas Muhammadiah Surakarta, 2012), 18.

${ }^{8}$ Asep Usman Ismail, Al-Qur'an Dan Kesejabtraan Sosial (Tangerang: Lentera Hati, 2012), 9.

${ }^{9}$ Choirul Mahfud, 39 Tokob Sosiologi Politik. Dunia (Surabaya: Jaring Pena, 2009), 40. word enough becomes their goal and orientation to the point that they have to spare themselves to work abroad. The phenomenon of migrant workers does not only happen to men, but women migrant workers also reap many entities as migrant workers abroad. In Indonesia, the phenomenon of migrant workers has spread to various regions, and several regions rank the highest as sending workers abroad, for example, West Java 31,027 people, Central Java 29,027 people, East Java 29.94 people, North Sumatra 27,381 people, East Lombok 10. 621 people and Central Lombok 6. 917 people. $^{10}$

It is a phenomenon that is quite a concern to be analyzed and studied. Seeing the entity and the existence of people who flocked to become migrant workers. Therefore, people who become migrant workers have touched all walks of life, for example, in Lombok, West Nusa Tenggara (NTB) is still reaping an escalating number of people becoming migrant workers, for example, in Central Lombok itself in 2019, it still reached 2,190 people who became migrant workers or complained abroad. ${ }^{11}$

Therefore, migrant workers as people who always want prosperity have to make their intentions to work abroad. but like many problems that occur abroad such as harassment, discrimination and human trafficking. ${ }^{12}$ So that the government implements several laws related to the protection of migrant workers abroad, for

${ }^{10} \mathrm{Https} / /$ Www.Suarantb.Com/Lombok.Ten gah/2017/03/25898/Loteng.Pengirim.Tki.Terbesar .Kelima.Nasional/. Di Akses Tanggal 15 Mei 2019 Jam 9:45 Wib. Di Akses Tanggal 12 Januari 2021.

${ }^{11}$ Data Placement and Protection for the Period of June 2019 (Pusat Penelitian Dan Pengembangan Informasi Gedung Bnp2tki), 4

${ }^{12}$ Ratna Mulihmmah, "Perempuan Dalam Belitan Problem Belitan Ketenagakerjaan," Jurnal Qawwam Vol 4, No 2 (2010): 3. 
example Law no. 18 of 2017 to protect migrant workers or Indonesian migrant workers (PMI) from acts of discrimination and so on about harming migrant workers in the destination country. ${ }^{13}$

UU no. 18 of 2017 is to ensure the implementation of the protection of migrant workers and the government takes part in the process of protecting and assisting migrant workers. The government is not only silent by looking at the problems of its people abroad, but the government must act whether it is the central government, village governments or agents from social organizations to ensure safe migrations. the government is not only silent by looking at the problems of its people abroad but the government must take action, whether it is the central government, to village governments or agents from social organizations, to ensure safe migrations. ${ }^{14}$

The role of social organizations or private organizations plays an active role in caring for migrant workers and providing assistance, namely Migrant Care which was born in 2004 from the initiation of several actors. ${ }^{15}$ Migrant Care has formed a village program to care for migrant workers or in short Desbumi, which exists in several regions in Indonesia. The purpose of Migrant Care in forming Desbumi is to encourage villages to form village regulations (perdes) related to the protection of migrant workers from the village, where agents or

${ }^{13}$ Anis Hidayah Dan Fitri Lestari Dkk, Migrant Care Perbimpunan Burub Migran Yang Berdaulat (Jakarta: Migrant Care, 2018), 7-9.

${ }^{14}$ Stella Aleida Hutagalung Dan Vito Tyas Indrio, Laporan Tematike Studi Midline Mampu Akses Perempuan Buruh Migran Luar Negeri Terhadap Layanan Perlindungan (The Smeru Research Institute, 2019), X.

${ }^{15}$ Endang Setyoningsih, Dra Fitriah, Dan Hermini, "Migrant Care Dalam Membantu Tki Bermasalah Di Arab Saudi Pada Tahun 2009 Dan 2010," Jurnal Ilmu Pemerintahan Undip Volume 2 Nomor 1 (2013): 5. implementers of the Desbumi program, namely those who have attended training organized by Migrant Care, are sent to the village. to drive the Desbumi program in every village. $^{16}$

According to Hidayah (2019), The Desbumi program is a protection strategy and assists migrant workers since they are still in the village, after work and until they return home from abroad to be empowered in their hometown. ${ }^{17}$ but this Desbumi was not born just like that, but there was a collaboration from Migrant Care with the Australian state in terms of empowering women called the Indonesia and Australia Partnership for Gender Equality (MAMPU).

Therefore, Darek Village is one of the villages in Central Lombok Regency, which has also made Village Regulation (Perdes) No. 04 of 2015, concerning the Protection of Migrant Workers. The Desbumi program is under the auspices of the Village Regulation (Perdes) as one of the village programs to protect and assist migrant workers in the village. because on the other hand, the village also has an explicit role in providing assistance to the community, for example, in Law no. 6 of 2014 Article 26 concerning increasing the capability of the government to build a prosperous and just society. ${ }^{18}$

Thus, the existence of the Desbumi Program will assist in the realization of the

${ }^{16}$ Baiq Ihtiar Nalara Mandalika, Strategi Pemberdayaan Mantan Buruh Migrant Wanita Studi Kasus Di Perkumpulan Panca Karsa (Pkk) Kota Mataram (Skripsi Uin Mataram Fakultas Dakwah Dan Ilmu Komunikasi, 2018), 56-57.

${ }^{17}$ Aleida Hutagalung Dan Tyas Indrio, Laporan Tematik Studi Midline Mampu Akses Perempuan Burub Migran Luar Negeri Terbadap Layanan Perlindungan, 15960.

${ }^{18}$ Abdur Rozaki, Dkk, Policy Papar Mengembangkan Model Pendampingan Desa Asimetris Di Indonesia (Jakarta: Institute For Research And Empowerment (Ire), 2016), 9-12. 
village government. This program will assist the protection and assistance of migrant workers from before working until their return to be given empowerment in their hometown. In this case, the problems that occur to migrant workers will be problems that the government must advocate, be it the village government. For example, in Darek Village, migrant workers often go through illegal routes because they do not know how to work abroad correctly due to a lack of access to migration.

In addition, the process of departing through the middleman route is still rampant, this is also due to the lack of attention from the village government. According to Wahyu Rudhanto, migrant workers who often experience problems are those who come from villages, weak access to information about migrant workers and lack of attention from the local village government. $^{19}$

Indeed, the problem of migrant workers departing using illegal routes is a common problem for migrant workers. ${ }^{20}$ Therefore, the Desbumi program aims to assist village performance in guiding its people who will work abroad. The Desbumi program is also a place for migrant workers to complain about problems, ask questions about proper and proper migration, and provide comfort for the migrant workers themselves. So that the Desbumi program can provide several essential things, namely providing information and conducting socialization of safe migration (safety migration) to the community to the hamlets,

${ }^{19} \mathrm{~A}$. Wahyurudhanto, "Kerja Sama Antar Negara Dan Penanganan Tindak Pidana Perdagangan Orang (Studi Kasus Indonesia Dan Malaysia)," Jurnal Ilmu Kepolisian Voluma 13, No. 1 (2019): 70.

${ }^{20}$ Laila Nagib, Studi Kebijakan Pengembangan Pengiriman Tenaga Kerja Wanita Ke Luar Negeri (Jakarta: Lipi, 2001), 10. helping to arrange files for prospective migrant workers, and helping to solve the problems of migrant workers.

For example, in 2016, the people of Darek Village, as migrant workers in Darek Village were almost imprisoned for trafficking and some were not given home by their employers. So that the implementers of the Desbumi program immediately consolidate and integrate with Migrant Care by sending notification letters and making a chronology of migrant worker cases. For this reason, the method often used is the Desbumi program implementer receiving cases from migrant workers, then the Desbumi program implementer integrates and notifies the Panca Karsa Association (PPK) Mataram City then to Migrant Care. Where is the Panca Karsa Association, a non-governmental organization oriented to empowering women and especially protecting migrant workers who collaborated with Migrant Care to help establish the Desbumi program in several villages in Central Lombok and one of them is Darek Village, Southwest Praya District, Central Lombok Regency.

\section{Methods}

This research will be using qualitative research or field research conducted in Darek Village, Southwest Praya District, Central Lombok Regency. The purpose of this study is to find out how the intensity and role of the Desbumi program in Darek Village are in assisting female migrant workers who will work abroad to become migrant workers, after working abroad and after returning to their hometowns in the village where they live. The data collection methods used in this study were interviews, documentation and field observations. Then the respondents in this study, researchers 
can implicate into two types. First, respondents from the Desbumi Desa Darek program implementers as stakeholders who assist migrant workers. Second, the respondents are migrant workers in the District of Praya Barat Daya, Central Lombok Regency.

\section{Discussion}

\section{Overview of the Desbumi Program in Darek Village}

The Desbumi program is one of the programs formed in collaboration with Migrant Care, supported by the IndonesiaAustralia Partnership for Gender Equality (MAMPU) program. Therefore, the Desbumi program assists migrant workers in various villages to assist migrant workers from the village after work and returning home to be empowered in the village.

According to Wulan (2017), The Desbumi program can arrange assistance and protection activities for migrant workers at the village level, provide migration access to the community, help solve community problems and empower former migrant workers in the village. ${ }^{21}$

Therefore, the desbumi program is under the auspices of village regulations (perdes). Where this village regulation was formed at the encouragement of migrant care who is supported by non-governmental organizations such as the Panca Karsa Association (PPK) which directly goes to villages so that Darek Village is one of the villages that forms village regulation (Perdes) No. 4 of 2015 concerning the protection of migrant workers.

${ }^{21}$ Tyas Retno Wulan, Dalhar Shodiq, Dan Wita Ramadhanti Dkk, "Perlindungan Buruh Migran Dari Hulu Ke Hilir Melalui Program Desa Peduli Buruh Migran (Desbumi): Studi Di Desa Kuripan Wonosobo Jawa Tengah Dan Desa Nyerot Lombok Tengah Nusa Tenggara Barat," Sodality: Jurnal Sosiologi Pedesaan Volume 5, No. 2 (Agustus 2017): 160.
The Desbumi program in Darek Village is driven by two stakeholders, namely the initials NH and M. They are the drivers of the Desbumi program in Darek Village. They did not immediately become Desbumi's movers. Instead, he attended training from Migrant Care on how to provide assistance to migrant workers. So with the formation of a Village Regulation (perdes), the Desbumi program has officially become a village program that focuses on assisting migrant workers from becoming prospective migrant workers, after working until they return home to be empowered in their hometown.

\section{Assistance of Women Migrant Workers in Darek Village through the Desbumi Program}

The Desbumi program is a program to assist migrant workers, especially women. In the respondent's explanation as the driver of the Desbumi program, Darek Village, Praya District, Southwest District, Central Lombok Regency, that the Desbumi program is indeed for the protection of migrant workers, but focuses more on women where women are far more likely to experience problems abroad such as discrimination, trafficking and other acts of harassment. $^{22}$

The Role and Function of the Desbumi Program in the Protection of Migrant Workers

a. Information Center The information center is a form of assistance carried out by Desbumi implementing cadres which aims to provide information in the form of socializing safe migration to the hamlet level. The method at this

\footnotetext{
${ }^{22} \mathrm{Nh}$, Wawancara, 2 Juni 2020.
} 
information center is that the Desbumi cadres convey information to the people of Darek Village to their homes by bringing the official Indonesian Migrant Workers (TKI) pamphlets, chatting directly with the people of Darek Village who will work abroad or with the families of migrant workers who are working abroad. Where the family has worked abroad regarding the importance of migrating through official channels, and informing the public of the dangers of migrating by illegal routes that are prone to getting into trouble abroad or in the destination country. ${ }^{23}$

The information center also aims at helping the community to choose jobs and safe migration destinations through official companies, where the Desbumi program cadres who accompany the people who migrate go through official channels, so that the Desbumi program can also get support from BNP2TKI Central Lombok Regency to help access the official company to be notified to the Darek Village community so that they continue to undergo the migration process through the official channel. In this case, the public may ask directly to the Desbumi program implementer regarding the departure to work abroad with an official PT, the community is accompanied more intensively by the Desbumi program implementer so that people can migrate safely (safety migrations). ${ }^{24}$

b. Mobility Data Center

The mobility data center is a form of assistance from the Desbumi Desa Darek program, which is oriented to

${ }^{23}$ Nh, Perempuan 29 Tahun, Wawancara 2 Juni 2020 Jam 10:11 Wita.

${ }^{24} \mathrm{M}$, Perempuan 26 Tahun, Wawancara $28 \mathrm{Mei}$ 2020 Jam 9:53 Wita. assist in making documents for the departure of people migrating in the village by the Desbumi program implementer. The mobility data center assists the community in managing migration departure documents such as Identity Cards (KTP), Family Cards $(\mathrm{KK})$, birth certificates and family permits for prospective migrant workers. The mobility data also aims to record the departure and return of migrant workers. It will help the village know how many people are working and who have returned from abroad as migrant workers.

c. Center for Case Complaints or Advocacy

The case complaint center is a form of assistance from the Desbumi program in handling cases or receiving cases in Darek Village communities abroad. Implementers of the Desbumi program can directly receive cases through social media from these migrant workers. However, sometimes the Desbumi program implementers face obstacles related to people who do not want to confirm the problem. After the establishment of the Desbumi Desa Darek program, now the community is advised to confirm the problem, where the Desbumi program implementer can advocate for the problems of the community and carry out a case handling mechanism by making a case chronology, after that the Desbumi program implementer integrates with related parties who help Desbumi performance such as the Perkumpulan PancaKarsa (PPK), Migrant CARE, BNP2TKI Central Lombok Regency 
and the Embassy of the Republic of Indonesia (KBRI). ${ }^{25}$

In this case, there are several roles of

the Desbumi program in providing assistance to migrant workers are:

1. Mentoring before working abroad

Assistance before work that is always carried out by the Desbumi program is to disseminate information to the community by bringing migration pamphlets that have been provided by Migrant Care and the BNP2TKI office in Central Lombok Regency. Then provide an opportunity for the community to ask questions about safe migration.

In addition, the implementers of the Desbumi program also provide direction and guidance that working abroad must now go through the process stages of the Desbumi program that already exists in the village and advise about the dangers of working through illegal channels or through the recruitment of brokers.

2. Assistance after work

Mentoring migrant workers through the Desbumi program after being abroad can be done by consolidation and integration with Migrant Care, PPK and BNP2TKI if they receive problems with migrant workers abroad.

The implementer of the Desbumi Desa Darek program also confirmed through social media namely Facebook and other media and informed that in the village there is now a Desbumi program to help with the problems of migrant workers, so that if migrant workers experience

${ }^{25 N h}$, Perempuan 29 Tahun, Wawancara 2 Juni 2020 10:22 Wita. problems, don't just stay silent and can tell the Desbumi Desa program implementers. Darek, Southwest Praya District, Central Lombok Regency.

For example, before the Desbumi program in the village, the community did not know whom to complain about their problems to, but after the Desbumi program, the community was advised not to remain silent about their problems, and the Desbumi program implementers were ready to provide protection and assistance.

3. Mentoring after becoming a former migrant worker

Post-employment assistance, namely, ex-migrant workers are directed to be empowered in the village with various empowerment approaches, namely making crackers, chips, sewing training and other soft skill activities.

This empowerment activity can be carried out in Darek Village and assisted by the village government, Migrant Care, the Panca Karsa Association (PPK) of Mataram City and the BNP2TKI of Central Lombok Regency.

A several former migrant workers with the initials $\mathrm{Hj}$. $\mathrm{N}$ said that.

"I am grateful that I can be empowered in the village by the Desbumi program. After I attended the training, now I can make a snack business and I can sell at home, even though the income is not much. Besides that, I was also taught sewing and many other things that I got after attending the training at the village office" 26

"The Desbumi program can help me in sewing. After the Corona outbreak, I was trusted to make masks by the village head. I and several other former migrant workers sewed masks in the village, I have even sewn 4000 masks with my income of 400 thousand

\footnotetext{
${ }^{26} \mathrm{Hj} . \mathrm{N}$, Interview, 6 Juni 2020.
} 
rupiah. During my training in the village, I was accompanied by several people from Migrant Care and Desbumi implementers in Darek Village. I can do this sewing business, even the sewing tools have been prepared by them, so we former migrant workers just stay diligent in carrying out the training and doing this business in the village" 27

The explanation from the Desbumi program implementer also provided several interview results, namely:

"In Darek Village I helped former migrant workers in strengthening the group's economy by forming a group called Latansa. This training unit consists of former migrant workers who we guide in terms of soft skills, make savings and loan group contributions by meeting every first week at the beginning of the month on Friday. This savings and loan money comes from money from former migrant workers, with an expenditure of $\mathrm{R}$. 10,000 for the initial fee and Rp. 5,000 once a meeting with the current latansa group, which now amounts to 40 members from former migrant workers from Darek Village". ${ }^{28}$

Therefore, from the Desbumi program, DesaDarek formed a group consisting of former migrant workers in DesaDarek called Latansa. In addition, former migrant workers identified as members of the Latansa group must be directed by the Desbumi program implementer to assist them in carrying out various productive economic activities in the village.

The Desbumi program implementer acts as a controller and companion in every activity of former migrant workers in the village. The Desbumi program implementer is also a broker in conveying information related to training activities in the village for former migrant workers, making masks

\footnotetext{
${ }^{27} \mathrm{Hj}, \mathrm{W}$, Interview, 3 Juni 2020.
}

${ }_{28}$ M, Interview, 2 Juni 2020 needed by the village to develop groups of former migrant workers.

$$
\begin{gathered}
\text { Chart 1: Organizational Structure of the } \\
\text { "Latansa" Care Group for Migrant Workers in } \\
\text { Darek Village. }
\end{gathered}
$$

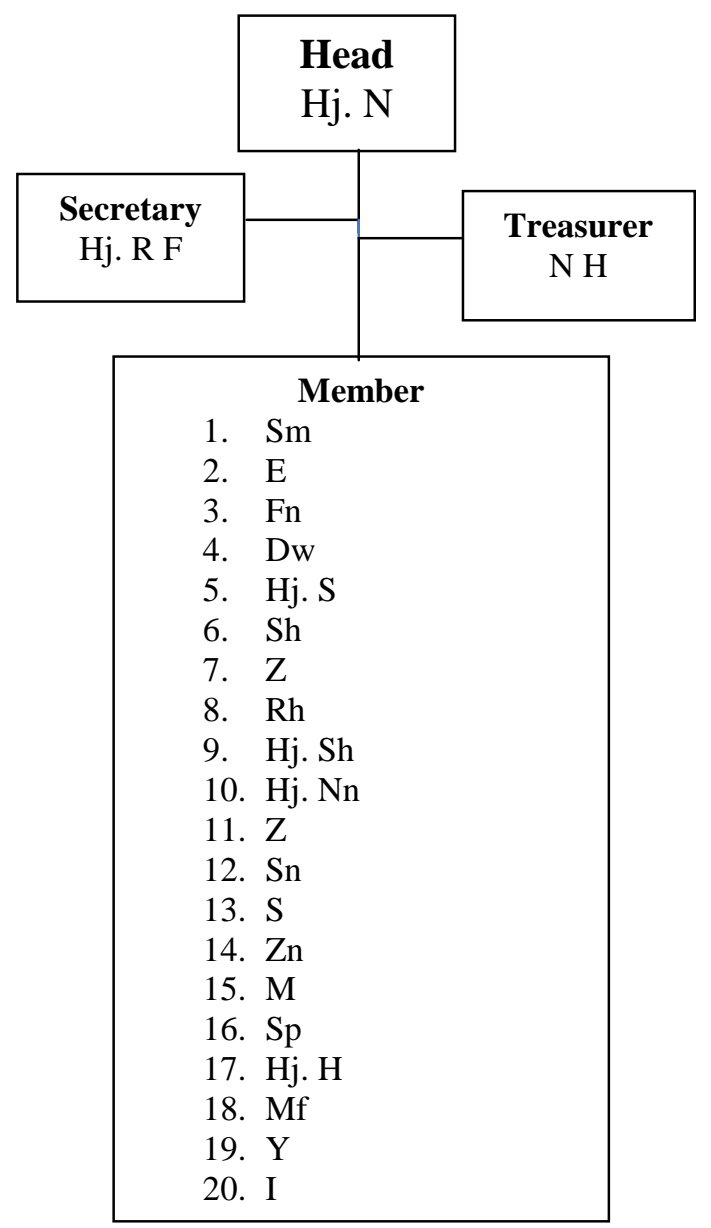

Former migrant workers can also conduct training activities once a month and issue group fees to activate groups and Latansa group members consist of former migrant workers and families of migrant workers engaged in group activities in the village. The routine activities of the Latansa group are conducting the Savings and Loans Business gathering (USP), skills training or soft skills at the village office and representing what they get in the training such as sewing, weaving and making snacks. Then the role of cadres implementing the Desbumi program was intensive in mobilizing members of the Latansa group in 
the village. ${ }^{29}$ The Desbumi program implementer always mediates and guides former migrant workers to continue to participate in carrying out productive activities in the village in strengthening the spirit of each member of the group they are assisted.

\section{The Purpose of the Desbumi Program in Solving the Problems of Female Migrant Workers in Darek Village}

Thus, the importance of the establishment of the Desbumi program down to the village level, namely: First, minimizing the departure data of prospective migrant workers in the village, so that people who want to work abroad can be recorded in the village as a form of responsibility and assistance from the village and program implementers Desbumi. For this reason, because the Desbumi program implementer must know how many people will migrate and who are returning from abroad, Desbumi also reviews the people who will return and must conform with the village. Second, people who accept problems where they work abroad are expected not to silence their problems. However, migrant workers from Darek Village must confirm their problems abroad to the village through the Desbumi program cadres so that they

${ }^{29}$ Softskill Training is aimed at Former Migrant Workers in Darek Village which is held once a month, namely on the second Friday of the week. Softskill training is carried out at the Darek Village Office and is followed by former migrant workers with speakers from the Migrant Care and Panca Karsa Association (Ppk) Mataram City, sometimes even from the Central Lombok Regency Manpower Office. The material presented in the training at the village office is related to the development of soft skills in the production of snacks, sewing, weaving and creation. Interview with M, 26 Years Old Female On 28 May 2020 at 9:42 WITA. can be given curative or defense (advocates). ${ }^{30}$

The importance of the Desbumi program in assisting and protecting migrant workers in the village is also an act for the benefit of the community, especially for people who become migrant workers abroad are:First, it is oriented to assistance and social protection for all Darek Village people who work as migrant workers abroad. Second, so that every community who will work abroad must follow the performance of the Desbumi program as the main forum in ensuring safe migration assistance (safety migrations) and as a place to process migration departure documents such as Identity Cards (KTP), Family Cards (KK) and permission letter from the prospective migrant worker's family.

Third, to reduce the number of migrants in Darek Village, so that the people of Darek Village do not become repeated migrant workers. The village government also prepares funds for empowerment of former migrant workers as a form of village contribution to the Desbumi program which has been based on the Darek village regulation (perdes) on the protection of migrant workers in the village. ${ }^{31}$

Table 1: the phenomenon of migrant workers before and after the establishment of the Desbumi program in Darek Village.

\begin{tabular}{|c|c|}
\hline $\begin{array}{l}\text { Before the } \\
\text { establishment of } \\
\text { the Desbumi } \\
\text { program }\end{array}$ & $\begin{array}{l}\text { After the } \\
\text { establishment of } \\
\text { the Desbumi } \\
\text { program }\end{array}$ \\
\hline $\begin{array}{l}\text { The village } \\
\text { government does } \\
\text { not record the } \\
\text { people who work } \\
\text { abroad }\end{array}$ & $\begin{array}{l}\text { - The village } \\
\text { government } \\
\text { collects data on } \\
\text { its people who } \\
\text { work abroad } \\
\text { through the } \\
\text { performance of } \\
\text { the Desbumi } \\
\text { program } \\
\text { implementers }\end{array}$ \\
\hline
\end{tabular}

${ }^{30} \mathrm{M}$, Female 24 Tahun, Interview 28 Mei 2020 at 10.09 Wita.

${ }^{31}$ Is, Male 48 Tahun, Interview 4 Februari 2020 at 8.50 Wita. 


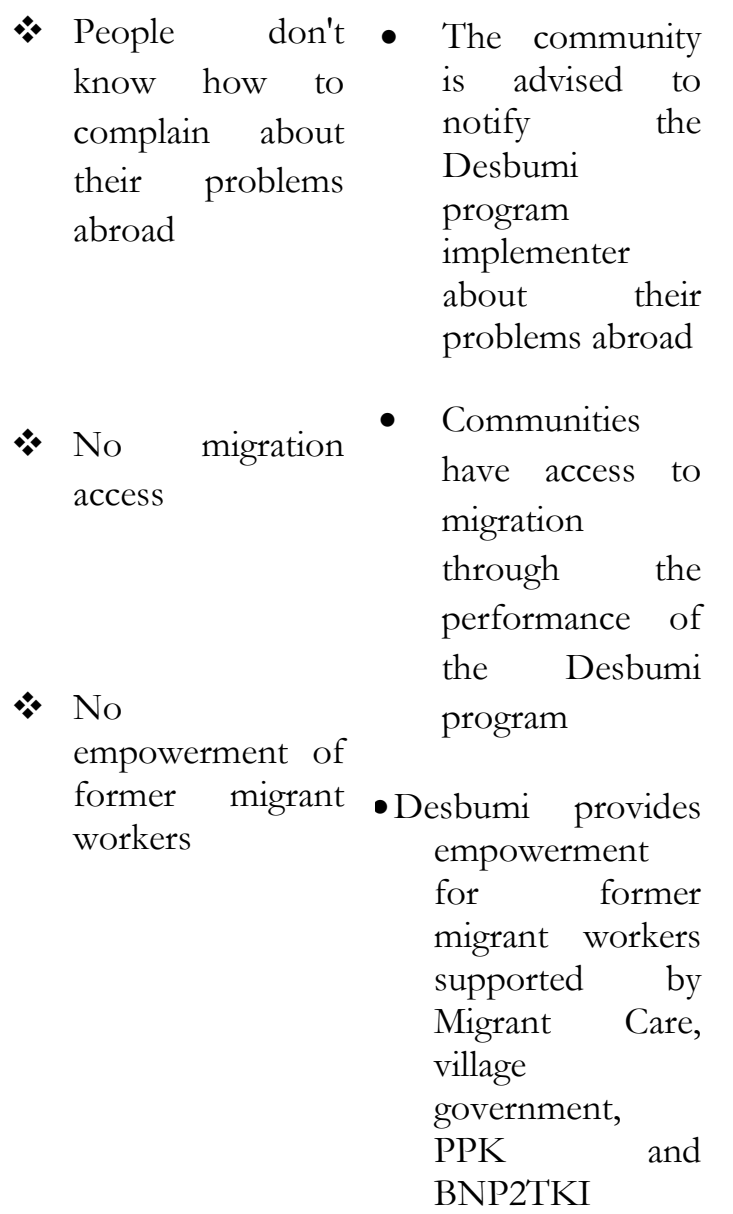

\section{Conclusion}

Problems with migrant workers are indeed part of the problems that must be covered. This study examines the role of assisting migrant workers, especially women in Darek village, through the Desbumi program. The Desbumi program has a role: First, an information center that aims to disseminate information about safe migration to the community so that people can migrate through legal channels. Second, the mobility data center, which helps migrant workers in managing departure documents such as ID cards, family cards, permits from families and others. Third, the advocacy center, which is to helps solve the problems of migrant workers abroad.
The Desbumi program also helps migrant workers, especially women, where female migrant workers are often vulnerable to problems abroad. In addition, the Desbumi program provides empowerment for former migrant workers or migrant workers who have returned to their hometowns by providing soft skill training in making snacks, sewing and others. And create a migrant worker care group consisting of former migrant workers by the name of Latansa.

\section{References}

\section{Journal}

Mulihmmah, Ratna. "Perempuan Dalam Belitan Problem Belitan Ketenagakerjaan." Jurnal Qawwam Vol 4, No 2 (2010).

Ni'matur Rohmah, Bubun. “Tingkat Kesejahtraan Ekonomi Keluarga Buruh Migran." Jurnal Penelitian Ilmiah Intaj Vol 1, No 1 (2017).

Retno Wulan, Tyas, Dalhar Shodiq, Dan Wita Ramadhanti Dkk. "Perlindungan Buruh Migran Dari Hulu Ke Hilir Melalui Program Desa Peduli Buruh Migran (Desbumi): Studi Di Desa Kuripan Wonosobo Jawa Tengah Dan Desa Nyerot Lombok Tengah Nusa Tenggara Barat." Sodality: Jurnal Sosiologi Pedesaan Volume 5, No. 2 (Agustus 2017).

Setyoningsih, Endang, Dra Fitriah, Dan Hermini. "Migrant Care Dalam Membantu Tki Bermasalah Di Arab Saudi Pada Tahun 2009 Dan 2010." Jurnal Ilmu Pemerintahan Undip Volume 2 Nomor 1 (2013).

Wahyurudhanto, A. "Kerja Sama Antar

Negara Dan Penanganan Tindak Pidana Perdagangan Orang (Studi Kasus Indonesia Dan Malaysia)." Jurnal Ilmu Kepolisian Voluma 13, No. 1 (2019). 
Zuhdan, Muhammad. "Perjuangan Gerakan Buruh Tidak Sekedar Upah Melacak Perkembangan Isu Gerakan Buruh Di Indonesia Pasca Reformasi." Jurnal Ilmu Sosial Dan Ilmu Politik Vol 17, No 3 Maret (2014).

\section{Books}

Aleida Hutagalung, Stella, Dan Vito Tyas Indrio. Laporan Tematik Studi Midline Mampu Akses Perempuan Buruh Migran Luar Negeri Terhadap Layanan Perlindungan. The Smeru Research Institute, 2019.

Hidayah, Anis, Dan Fitri Lestari Dkk. Migrant Care Perbimpunan Burub Migran Yang Berdaulat. Jakarta: Migrant Care, 2018.

Khaldun, Ibnu. Muqoddimah. Jakarta: Pustaka Firdaus, 2008.

Kurniawati, Novie. "Prilaku Berpacaran Pada Remaja Usia Madya: Studi Kasus Di Daerah Di Kaupaten Merangin Provinsi Jambi." Skripsi Universitas Muhammadiah Surakarta, 2012.

Mahfud, Choirul. 39 Tokoh Sosiologi Politik Dunia. Surabaya: Jaring Pena, 2009.

Nagib, Laila. Studi Kebijakan Pengembangan Pengiriman Tenaga Kerja Wanita Ke Luar Negeri. Jakarta: Lipi, 2001.

Nalara Mandalika, Baiq Ihtiar. Strategi Pemberdayaan Mantan Burub Migrant Wanita Studi Kasus Di Perkumpulan Panca Karsa (Pke) Kota Mataram. Skripsi Uin Mataram Fakultas Dakwah Dan Ilmu Komunikasi, 2018.

Rozaki, Dkk, Abdur. Policy Papar Mengembangkean Model Pendampingan Desa Asimetris Di Indonesia. Jakarta: Institute For Research And Empowerment (Ire), 2016.

Sabhana Azmy, Ana. Negara Dan Buruh Migran Perempuan. Jakarta: Obor Indonesia, 2012.

Sari, Dian Permata. "Analisis Peran Tenaga Kerja Wanita Di Luar Negeri Dalam Meningkatkan Pendapatan
Keluarga Menurut Perspektif Ekonomi Islam." Skripsi: Universitas Raden Intan Lampung, 2017.

Suseno, Franz Magnis. Pemikiran Karl Marx Dari Sosialisme Utopis Ke Perselisiban Revisionisme. Jakarta: Pt Gramedia Pustaka Utama, 2005.

Usman Ismail, Asep. Al-Qur'an Dan Kesejabtraan Sosial. Tangerang: Lentera Hati, 2012. 